\title{
Does the closed fishing season influence the ichthyofauna consumed by Larus dominicanus?
}

\author{
Maiara Larissa Miotto*, Barbara Maichak de Carvalho, Henry Louis Spach
}

Universidade Federal do Paraná

(Av. Beira-Mar, s/n, CEP 83255-976, caixa postal 61, Bal. Pontal do Sul, Pontal do Paraná, PR - Brazil)

*Corresponding author: miotto.maiara@gmail.com

\begin{abstract}
Fish that are incidentally caught by shrimp trawling represent a predictable and abundant resource for feeding several bird species, especially for the gull Larus dominicanus. This fishing activity is subject to disruptions throughout the year during closed fishing seasons, when other fishing modalities are exercised, which can alter the composition, abundance and size of the fish bycatch. This study evaluated the influence of the restriction of fishing period of shrimp (closed season) on the diet of $L$. dominicanus, on the Paraná State coast. From December 2013 to August 2014, 10 pellets were collected per month in two distinct areas that have shrimp trawl fishery as the main economic activity: one continental and another in an estuarine island. In total, 920 fish were identified, divided into four families and 15 species, especially the family Sciaenidae with 11 species. There were differences in abundance and biomass of species between areas and between seasons of pre-closure, closure and post-closure. Differences for the mean total length of the species were only detected between the pre-closed and closed seasons in one area. This study evidenced the strong relationship between $L$. dominicanus and the shrimp trawl fishery, the species composition identified in the pellets and their respective morphometric measurements follow the same pattern of the literature for fish discarded in trawling activities.
\end{abstract}

Descriptors: Bycactch, Shrimp trawling, Closing season, Seabirds, Brazil.

\section{Resumo}

As capturas incidentais de peixes no arrasto do camarão representam um recurso abundante para a alimentação de muitas aves, sobretudo para a gaivota Larus dominicanus. O presente estudo avaliou a influência do defeso da pesca de arrasto do camarão sobre a dieta de L. dominicanus no litoral do estado do Paraná. Entre dezembro de 2013 e agosto de 2014 foram coletados 10 pellets alimentares por mês em duas áreas distintas, em períodos sem e com a influência do defeso do camarão sete-barbas. Ao todo, foram identificados 920 peixes, divididos em quatro famílias e 15 espécies, com destaque para a família Sciaenidae, com 11 espécies. Foram identificadas diferenças na abundância e biomassa das espécies entre as áreas e entre os períodos de pré-defeso, defeso e pós-defeso. Diferenças em relação ao comprimento total médio das espécies só foram encontradas entre o pré-defeso e defeso em uma das áreas. Com este trabalho, foi possível observar a forte relação entre $L$. dominicanus e a pesca de arrasto do camarão, a composição das espécies identificadas nos pellets e as estimativas de comprimento seguem o mesmo padrão do que a literatura traz para os peixes descartados nas atividades de arrasto.

Descritores: Descarte de pesca, Pesca do camarão, Defeso, Aves marinhas, Brasil. 


\section{INTRODUCTION}

Fishing discards represent a predictable source of food in time and space, with high energy value, which can lead to dependency of some seabirds on these resources, and increase their population growth (SILVA et al., 2000; GIACCARDI; YORIO, 2004; YORIO; CAILLE, 2004). Several studies have shown that changes in fishing due to severe winters and the closed fishing season influence the diet composition, reproductive success, body mass and distribution of seabirds that are associated with such discards (HÜPPOP; WURM, 2000; ARCOS et al., 2001; BARBIERI, 2010; TRAVERSI; VOOREN, 2010; CARNIEL; KRUL, 2012).

An example of seabird that takes advantage of fishing discards is the gull Larus dominicanus (Lichtenstein, 1823). This species is one of the most common and frequent gulls in the southern Brazilian coast, with generalist and opportunistic feeding behavior, which favors the incorporation of fishing discards in the diet (YORIO et al., 1998; WHITTINGTON et al., 2006). Thus, alterations in fishing activity can cause changes in the feeding of this species, thus influencing the reproductive process of the population.

Just like some birds of prey and other seabirds, seagulls cannot digest some hard parts of their prey, such as fish otoliths, and regurgitate them as pellets (SIMMONS et al., 1991; PETRACCI, 2002; LUDYNIA et al., 2005). The fragments that form the pellets can be identified, counted and measured, thereby providing estimates of the number and size of ingested items (BUGONI; VOOREN, 2004).

During the shrimp closed season fishermen change their fishing gear to more selective methods, which capture least species with larger sizes. So if Larus dominicanus interacts with the fishing during the closed season, we expect to find a few species, however, with longer lengths, in its diet. In this way, aiming to evaluate the influence of changes in fishing activity on the diet of $L$. dominicanus, this study characterized the fish food items found in pellets of this seagull before, during and after the closure of shrimp fishing on the coast of the Paraná State.

\section{MATERIAL AND METHODS}

\section{STUDY AREA}

The Paraná State coast has about $90 \mathrm{~km}$ of coastline and is bordered to the north by the Varadouro Channel $\left(25^{\circ} 12^{\prime} \mathrm{S}\right)$ and to the south by the mouth of the Saí-Guaçu
River ( $25^{\circ} 58^{\prime}$ S) (Figure 1). The sedimentary cover of the continental shelf consists mostly of sand, mud and clay, and with the exception of a few rocky substrates bordering the islands, the continental shelf is dominated by sandy bottoms (BIGARELLA, 2001).

On this same coast, the trawl fishing is the most used technique by the artisanal fleet. This is because shrimps represent the main fishery resources exploited in this region (PAIVA, 1997), whose capture is mainly performed by trawling. It is currently in force the Instruction 189/2008, which bans this fishing mode in the period from March $1^{\text {st }}$ to May $31^{\text {st }}$, applying to pink shrimp (Farfantepenaeus brasiliensis, F. paulensis and F. subtilis), seabob shrimp (Xiphopenaeus kroyeri), white shrimp (Litopenaeus schmitti), red shrimp (Pleoticus muelleri) and South American shrimp (Artemesia longinaris).

For this study, we selected two different areas of the coast: North area, which refers to the Superagui Island that is inserted in the Environmental Protection Area of Guaraqueçaba $\left(25^{\circ} 26^{\prime} \mathrm{S}\right.$ and $\left.48^{\circ} 13^{\prime} \mathrm{W}\right)$ and South area, Barrancos beach, in the municipality of Pontal do Paraná ( $25^{\circ} 36^{\prime} \mathrm{S}$ and $\left.48^{\circ} 24^{\prime} \mathrm{W}\right)$ (Figure 1).

\section{SAMPLING}

Pellet samplings were conducted from December 2013 to August 2014 in three seasons: pre-closure (December, January and February), closed season (March, April, and May) and post-closure (June, July and August).

In each area, we collected 10 pellets per month, totaling 30 pellets per unit area in each period, 90 pellets per area when added three periods and 180 pellets in total. To make sure the pellet to be collected was from $L$. dominicanus, we colletcted only in places with the presence of specific mono flocks. Once collected, these pellets were taken to the laboratory and oven dried at $80^{\circ} \mathrm{C}$ for approximately 90 minutes.

\section{SAMPLE ANALYSIS}

Otoliths found in the pellets were used for identification and quantification of fish ingested by $L$. dominicanus. Only the otoliths with preserved structures were identified and measured. The identification was carried out by using otolith structures according to the literature (CORRÊA; VIANA, 1992; ABILHÔA; CORRÊA, 1992; LEMOS et al., 1992; LEMOS et al., 1995; DI BENEDITTO et al., 2001; CARVALHO et al., 2014; ROSSI-WONGTSCHOWSKI et al., 2014). 


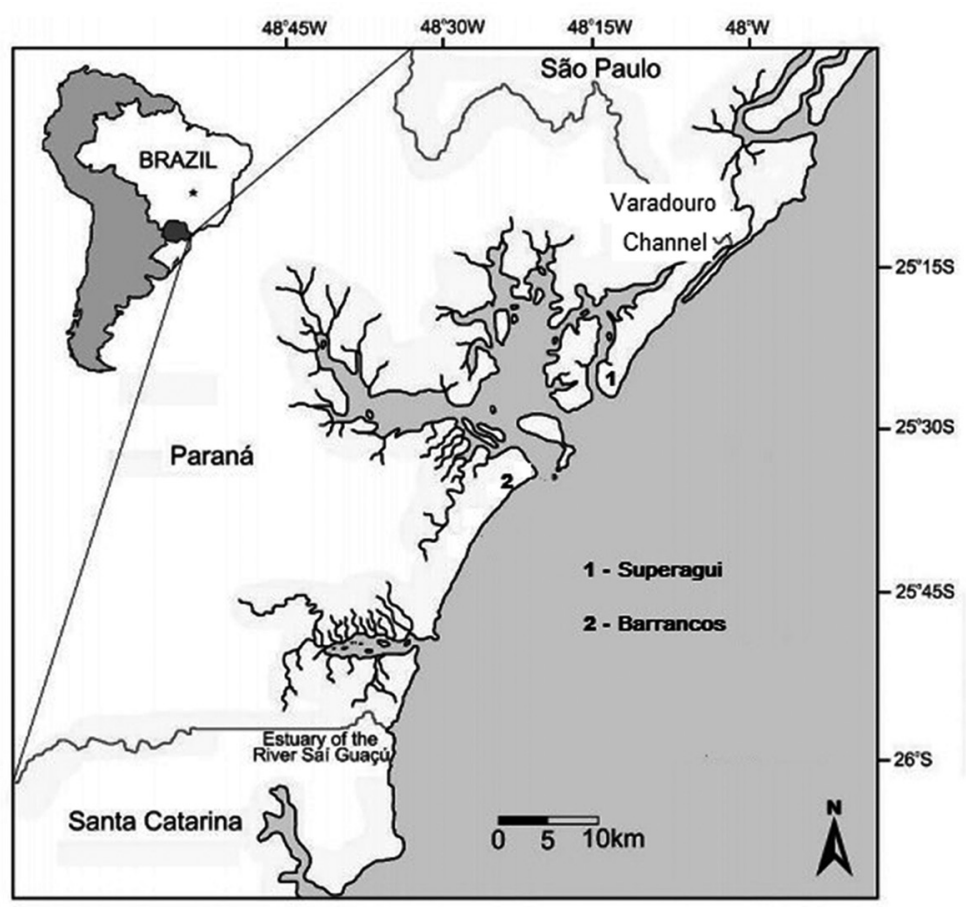

Figure 1. Map of the Paraná State coast showing the areas of study: 1 - Superagui Island; 2Barrancos beach. (Source: Adapted from Carniel and Krul, 2012).

The length and weight of ingested fish were estimated by measuring the otolith length (the longest distance between the anterior and posterior margins) and ventral height of the otolith (longer straight distance, between a central point of intersection of the tail with the ostium and the ventral margin). These measurements were taken with a stereoscopic microscope with ocular micrometer $(0.1$ $\mathrm{mm})$. From these measurements, we estimated the length and weight of the identified teleost fish based on regression equations available in the literature (CORREAA; VIANA, 1992; DI BENEDITTO et al., 2001; CARVALHO et al., 2014).

The quantification of fish was made from the separation of otoliths into right and left, which considered the position of the sulcus acusticus and the rostrum. Each pair of otoliths of the same species with very similar morphometric represented one fish.

To calculate the importance of each fish species in the diet, we determined: 1) FO: frequency of occurrence in the pellets, or the number of pellets with the occurrence of a certain species, 2) $\mathrm{FO} \%$ : relative frequency of occurrence of each species 3) $\mathrm{N}$ : number of individuals of a certain species present in the pellets, 4) N\%: numerical proportion of each species in the diet, that is, $\mathrm{N}$ as a percentage of the total number of individuals of a certain species, 5) M: weight of each species present in the pellets and 6) M\%: weight percentage of each species in the diet, i.e., $\mathrm{M}$ as a percentage of the total weight of all the fish in the sample 7) IRI, index of relative importance IRI $=(\mathrm{N} \%+\mathrm{M} \%)$ FO\% modified from PINKAS et al. (1971).

The spatial and temporal differences of the diet were tested by PERMANOVA using a mixed linear model, the fixed factor were the areas (Barrancos and Superagui) and the random factor were the seasons (pre-closure, closure and post-closure) nested within the areas, with $\alpha=0.05$. PERMANOVA is the analysis of univariate or multivariate variance, which uses permutation procedures based on any measure of similarity. The advantage of this type of analysis is the lack of assumptions, such as normality. Thus, it is a nonparametric test that allows the use of fixed or random factors related in orthogonal manner or nested in descriptive or experimental hypothetical models. (ANDERSON et al., 2008).

For graphical representation of differences detected by PERMANOVA, a canonical analysis of principal coordinates (CAP) was run, which generates the graphical clusters through 9999 permutations (ANDERSON et al., 2008). Within the CAP analysis, Spearman correlations $(\alpha=0.05)$ were used to determine which fish species were responsible for the clusters. 


\section{RESULTS}

The analysis of 180 pellets allowed the identification of 920 fish of four families, 334 in Barrancos and 586 in the Superagui Island. The family Sciaenidae was the most representative with eleven species, namely: Ctenosciaena gracillicirrhus, Cynoscions jamaicensis, Isopisthus parvipinnis, Larimus breviceps, Macrodon ancylodon, Micropogonias furnieri, Nebris microps, Paralonchurus brasiliensis, Pogonias cromis, Stellifer brasiliensis, Stellifer rastrifer. Lower diversity was found in families Ariidae, with two species, Cathorops spixii and Genidens genidens, Engraulidae with one species, Lycengraulis grossidens, and Haemulidae with one species, Pomadasys corvinaeformis (Table 1).

$S$. rastrifer was the most important species in pellets of Barrancos, with the highest values of abundance, frequencies of occurrence and indices of relative importance in the seasons analyzed (Table 1). In the pellets collected in Superagui, C. spixii was the most representative species with the greatest abundance, frequencies of occurrence and the highest indices of relative importance in all seasons analyzed (Table 1).

There was distinction for length of fish consumed by gulls between sites and seasons. In Barrancos, fish individuals with longer total length (TL) were found in the post-closure and corresponded to L. breviceps $(27.23 \mathrm{~cm})$, M. ancylodon $(25.05 \mathrm{~cm})$ and I. parvipinnis $(23.49 \mathrm{~cm})$ (Table 2). S. rastrifer showed a wide range in all seasons; the lowest TL was observed during the pre-closure in both areas $(4.76 \mathrm{~cm})$, and the highest TL in Barrancos during the closed fishing season $(19.47 \mathrm{~cm})$. Shorter lengths were associated with the pre-closure season (Table 2).

In the Superagui Island, C. spixii showed the greatest range in length with the lowest TL verified in the preclosure season $(4.43 \mathrm{~cm})$, while the highest TL was in the post-closure season $(20.23 \mathrm{~cm})$. C. jamaicensis $(20.65 \mathrm{~cm})$ and $S$. brasiliensis $(21.96 \mathrm{~cm})$ also showed the longest lengths in the Superagui Island, during the post-closure (Table 2).

The PERMANOVA indicated significant variations in abundance between areas (PERMANOVA: $\mathrm{DF}=1$, Res=160, MS=57,958, Pseudo-F=4.16, $p=0.0106$ ) and between seasons within each area (PERMANOVA: $\mathrm{DF}=4$, Res=160, MS=13,962, Pseudo-F=5.30, $p=0.0001$ ).

In Barrancos, the pairwise comparison by PERMANOVA evidenced significant differences in abundance between the pre-closure and closed seasons $(\mathrm{t}=2.44, p=0.0001)$, pre-closure and post-closure $(\mathrm{t}=2.58$, $p=0.0001)$ and between the closed and post -closure $(\mathrm{t}=2.02, p=0.0008)$. Fish abundance was also significantly different in the Superagui Island between the pre-closure and closed seasons $(\mathrm{t}=1.58, p=0.0152)$, pre-closure and post-closure $(\mathrm{t}=2.10, p=0.0003)$ and between the closed and post-closure $(\mathrm{t}=2.02, p=0.0017)$.

The differences between the mean values of abundance detected between the seasons by PERMANOVA as well as species that have contributed to these differences can be observed in graphics of the canonical analysis of principal coordinates (CAP) (Figure 2). The high abundance of $S$. brasiliensis in the pellets of the pre-closure season and $S$. rastrifer in those of the post-closure justify these differences (Figure 2). The canonical correlation of the two axes obtained by the analysis was $\delta_{1}=0.6022$ and $\delta_{2}=0.4859$. There was a clear separation associated with the axis 1 between the pellets of the pre-closure and the closure and post-closure of the two areas, and associated with the axis 2 , there was separation between the postclosure and pre-closure seasons (Figure 3).

Variations between areas (PERMANOVA: $\mathrm{DF}=1$, Res=156, $\mathrm{MS}=26,272$, Pseudo-F=2.39, $p=0.0272$ ) and seasons (PERMANOVA: $\mathrm{DF}=4, \mathrm{Res}=156, \mathrm{MS}=11,017$, Pseudo-F=2.94, $p=0.0001$ ) in fish biomass present in L. dominicanus pellets were significant. The paired comparison in Barrancos by PERMANOVA showed significant differences in biomass between the pre-closure and closed seasons $(\mathrm{t}=1.83, p=0.0011)$, pre-closure and post-closure $(\mathrm{t}=1.87, p=0.0005)$ and between the closed and post-closure seasons $(\mathrm{t}=1.73, p=0.0015)$. The paired test also evidenced significant differences in the biomass of fish present in the pellets of the Superagui Island between the pre-closure and closed seasons $(\mathrm{t}=1.49, p=0.0159)$, pre-closure and post-closure $(\mathrm{t}=1.54, p=0.0127)$ and between the closed and after-closure $(\mathrm{t}=1.80, p=0.0004)$.

The differences between the mean values of biomass detected between areas and seasons by PERMANOVA as well as species that contributed to these differences were illustrated in the ordination of the canonical analysis of principal coordinates (CAP) (Figure 3). The canonical correlation of the two axes obtained by the analysis was $\delta_{1}=0.5853$ and $\delta_{2}=0.5186$. There was a clear separation associated with the axis 1 , between the pellets of the closed and after-closure seasons and, associated with the axis 2 , there was a separation between the pellets of the closed and pre-closure seasons (Figure 2). The high biomass of $M$. furnieri and C. jamaicensis in the pellets of the closed 







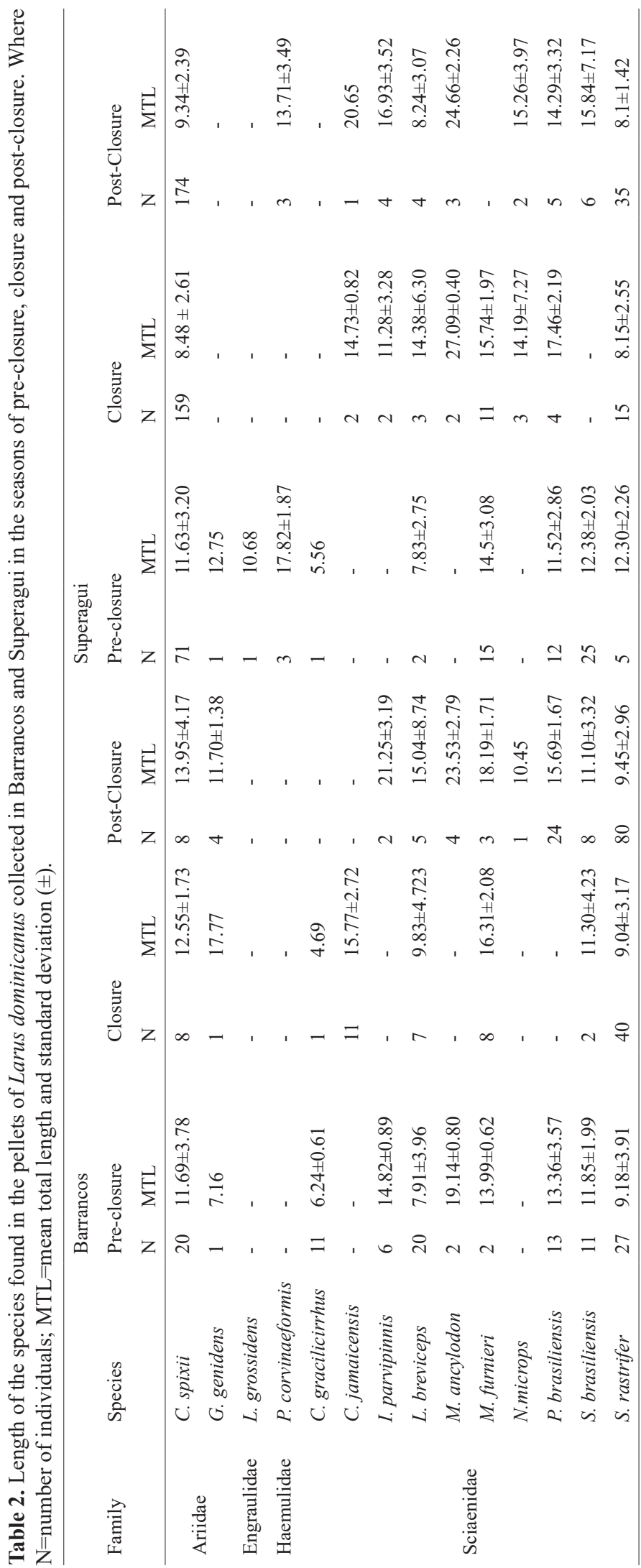




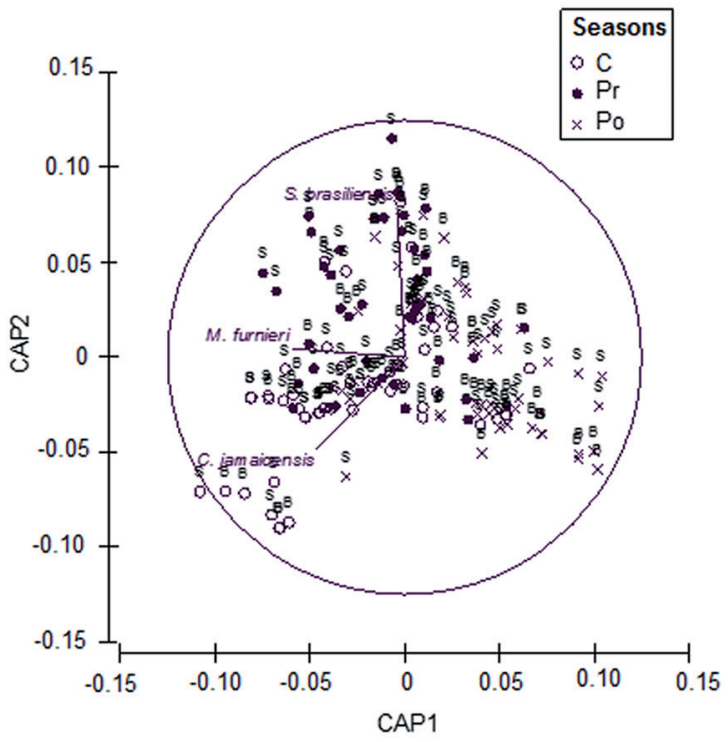

Figure 2. Result of the canonical analysis of principal coordinates (CAP), with fish that contributed most in number of individuals for the differences between sites and seasons. Fish vectors based on Spearman correlation of 0.5 ( $\mathrm{B}=$ Barrancos, $\mathrm{S}=$ Superagui, $\mathrm{C}=$ closed, $\mathrm{Pr}=$ pre-closure, $\mathrm{Po}=$ post-closure).



Figure 3. Result of the canonical analysis of principal coordinates (CAP), with fish that contributed most in biomass for the differences between sites and seasons. Fish vectors based on Spearman correlation of $0.5 \quad(\mathrm{~B}=\mathrm{Barrancos}, \mathrm{S}=$ Superagui, $\mathrm{C}=$ closed, $\mathrm{Pr}=$ pre-closure, $\mathrm{Po}=$ post-closure).

season in Barrancos and S. brasiliensis in the pre-closure season in Barrancos and Superagui were responsible for these differences (Figure 3).

There were no significant differences between the areas for the mean values of total length (TL) (PERMANOVA: $\mathrm{DF}=1, \mathrm{Res}=156, \mathrm{MS}=12,093$, Pseudo-F=0.77, $p=0.3438$ ). A significant difference in mean total length was observed between the sampling periods (PERMANOVA: $\mathrm{DF}=4$, Res=156, MS=12,480, Pseudo-F=3.17, $p=0.0029$ ). No statistical differences were found in the paired comparisons (PERMANOVA pairwise test) between the seasons sampled for Barrancos. In the Superagui Island, the only variation in length was registered between the closed and post-closure seasons ( $\mathrm{t}=1.48, p=0.0352$ ).

In the canonical analysis of principal coordinates (CAP), the canonical correlation of the two axes was $\delta_{1}=0.5504$ and $\delta_{2}=0.5186$ and indicated a difference between the pre-closure and closed seasons due to the contribution of the total lengths of $S$. brasiliensis in the pre-closure (Figure 4).

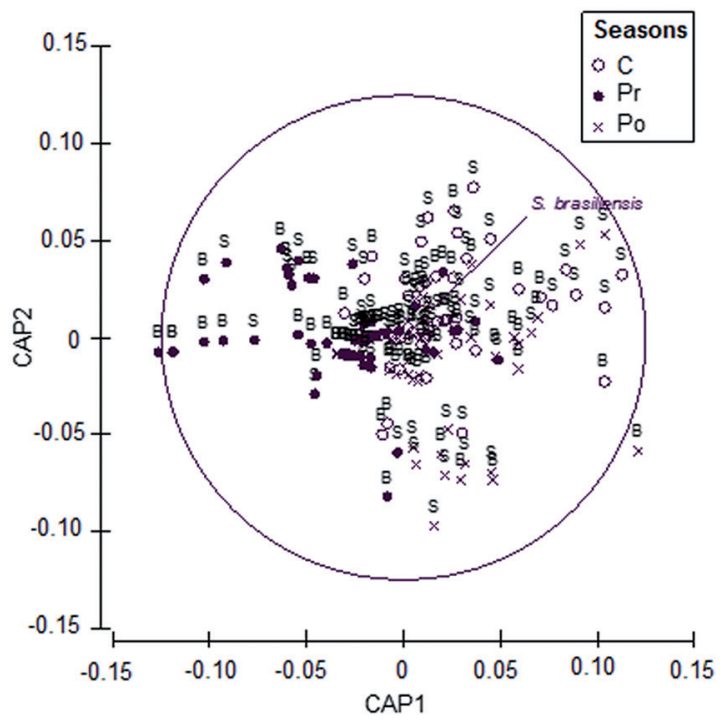

Figure 4. Result of the canonical analysis of principal coordinates (CAP), with fish that contributed most with length for the differences between sites and seasons. Fish vectors based on Spearman correlation of 0.6 ( $\mathrm{B}=$ Barrancos, $\mathrm{S}=$ Superagui, $\mathrm{C}=$ closed, $\mathrm{Pr}=$ pre-closure, $\mathrm{Po}=$ post-closure).

\section{DISCUSSION}

The family Sciaenidae contributed with the highest number of species analyzed, as also reported in other studies (BRANCO et al., 2006; SILVA-COSTA; BUGONI, 2013) which recognize the importance of this family in the composition of the diet of seabirds in southern Brazil. A great representativeness of the family Sciaenidae in discards and consequently in the pellets reflects the structure of the fish community of the southeast-south region of Brazil, where this family is dominant both in number of species and biomass (CATTANI et al., 2011).

In general, C. spixii, L. breviceps, P. brasiliensis and $S$. rastrifer were the most representative in $L$. dominicanus diet throughout the study, occurring in all seasons and in both sites. 
These species are described as the most frequent and with more individuals present in discards of seabob shrimp trawling in southern Brazil (SOUZA; CHAVES, 2007; PINA; CHAVES, 2009). This fact proves the generalist and opportunistic feeding behavior of $L$. dominicanus, since it uses the resources that are more abundant and widely available in time and space as is the case of the discard of shrimp fleet (WHITTINGTON; MARTIN, 2006; CARNIEL; KRUL, 2012; SILVA-COSTA; BUGONI, 2013).

The diet of L. dominicanus differed between areas. Stellifer rastrifer contributed most to the samples from Barrancos, being the most important fish species of this area. This is a result of the abundance of this species compared to the other teleost species caught incidentally by seabob shrimp trawling, accounting for $30 \%$ of discarded fish fauna near Barrancos (CATTANI et al., 2011). In the Superagui Island, Cathorops spixii was the species contributing most to the composition of fish fauna in L. dominicanus diet. This is probably a reflection of the greater abundance and concentration of this species in this area (CHAVES et al., 2003; CATTANI et al., 2011), where there is predominance of very fine sediments (silt and clay) at depths less than $10 \mathrm{~m}$ (VEIGA et al., 2004), which could favor the concentration of this species in these areas. SCHWARZ et al. (2006) states that $C$. spixii is the most abundant species in the surroundings of Superagui, mainly at $9 \mathrm{~m}$ deep, where trawling activities are concentrated. As this species does not have high economic value (CATTANI et al., 2011), it is often discarded in large quantities in this area and its surroundings.

The species abundance also showed variations between seasons in both areas. During the post-closure in Barrancos, $S$. rastrifer was responsible for major contributions, possibly reflecting the greater abundance of fish during this season, due to the interval between trawls. During the closed season, the fishing effort is reduced, which reduces the stress caused to the environment, favoring a greater increase in populations of this species and consequently it contribution in discards. According to BERNARDO et al. (2011), S. brasiliensis is abundant in regions close to the Superagui Island and can be considered a feeding and growth area, as the authors found maturing and mature individuals. S. brasiliensis exhibited a high incidental catch in the Santa Catarina State in the summer (FREITAS et al., 2011). The studies mentioned above confirm the greater abundance of otoliths of this species in the pre-closed season, which refers to the summer months in this region.

Biomass of fish analyzed in the pellets also showed significant differences between the sites and seasons. During the closed season in Barrancos, Cynoscion jamaicensis was responsible for the second largest contribution to the composition of the fish fauna in the diet. This species was found only in this area and during this season, which may be related to the closed fishing season of shrimp trawl. Unable to use the trawl, fishermen begin to use other fishing gear, such as driftnet and fixed gillnets (ARCOS et al., 2001; CHAVES; ROBERT, 2003), modalities that generate discards only during the fish cleaning on the beach, in the form of offal and carcasses.

During the shrimp trawl, CATTANI et al. (2011) found a wide size range in $C$. jamaicensis, ranging between 2 and $20 \mathrm{~cm}$, but the most frequent size class was between 8 and $10 \mathrm{~cm}$. From $19 \mathrm{~cm}$, individuals of this species are already adult (VAZZOLER; BRAGA, 1983; CASTRO et al., 2002) and as this species has a high commercial value (CATTANI et al., 2011) it is possible that the gull has fed only on head or carcass of these individuals, which has possibly been discarded on the beach, as the region of Barrancos presents a routine handling of fish on the beach that provides discards and portions not marketed or consumed. Other species with high representativeness during the closed season in this area was Micropogonias furnieri, often caught incidentally by driftnet and fixed gillnets (CHAVES; ROBERT, 2003), which confirms the use of discards of other fishing gear by L. dominicanus during the closed fishing season.

Length described for the species consumed by $L$. dominicanus in both areas and seasons corresponded to the sizes described for fish discarded in shrimp trawling by GRAÇA-LOPES et al. (2002), on the coast of São Paulo State and CATTANI et al. (2011), for the Paraná State coast. These results corroborate GONZÁLES-SOLIS (2003); KRUL (2004) and SILVA-COSTA and BUGONI (2013), which claim that fishery discards are an important food resource for seagulls, and in many cases the main components of the diet.

The statistical analysis detected no significant changes in Barrancos relative to the size of the species found in the pellets between seasons. However, it was observed a pattern of growth of the species between the pre-closure and closed seasons. In the pre-closure, it was registered lower lengths among the species, coinciding with greater abundance of juveniles and/ or recruits of the species identified in this study in the areas used by the shrimp fleet (CHAVES et al., 2003), which may have resulted in the incidental catch of small individuals without commercial value (GOMES; CHAVES, 2006), which were discarded. On the other hand, in the post-closure, it was possible to observe a greater number of species with individuals of longer lengths. The trawled areas have favorable conditions to sciaenids in terms of turbidity and energy supply, since large part of the bottom substrate has very fine to fine sand (VEIGA et al., 2004), favoring entrapment and the occurrence of organic matter and associated benthic macrofauna. FIGUEIREDO and MENEZES (2000) report the preference of sciaenids for fine 
sediments; in this way, they respond to the reduction in fishing pressure and return to these areas. So when the trawl fleet is back, it incidentally capture these individuals with larger sizes and greater abundances.

Moreover, other hypotheses raised for the presence of larger individuals during the post-closure season is the entrance of several cold fronts from the southeast and southern regions during the winter, which favors a coastal hydrodynamic circulation pattern that results in superelevation of the sea level and/or increased coastal wave, which prevents the achievement of trawls, favoring the use of other fishing gear, such as driftnet, which in turn catch larger fish. There is still the low season of tourism in this season, resulting in a lower demand for fish, so that great part that is not used for consumption of fishermen could be discarded on the beach.

This pattern of growth between the pre-closure and post-closure seasons was not found for the fish present in the pellets collected in the Superagui Island. This may be a consequence of non-compliance or partial compliance of the closed fishing season. According to MALHEIROS** (personal communication), in the village of Superagui, in 2003, the closed season was virtually ignored, i.e., the shrimp fleet continued acting between March and May. The statistical analysis on fish length data relative to Superagui between the seasons pointed out significant differences between the pre-closure and closed seasons, a difference that was probably related to Stellifer brasiliensis, which had the highest mean values of length during the pre-closure. But this species was not found during the closed season, which may have caused this difference.

It was evidenced a strong relationship and dependence of gulls of the Paraná State coast with fishing activities, especially those that provide large amounts of discards, as is the case of shrimp trawling. Owing the analysis of the pellets, it was also possible to identify qualitatively and quantitatively fish populations that comprise discards of shrimp trawlers, since our findings basically followed the same pattern found in the literature.

The differences found in L. dominicanus diet in relation to abundance, biomass and total length of the species over the periods, and between areas may be associated with environmental conditions, such as availability of fish in areas of trawling and weather conditions, and changes in fishing gear during the period of closure. Thus, it can say that changes in the environment caused by internal and external factors have been found in L. dominicanus diet.
Thus, the use of pellets of these species could be useful for rapid assessments on fishing in certain areas, given the advantages of low cost besides being a rapid and noninvasive method.

\section{REFERENCES}

ABILHÔA, V.; CORRÊA, M. F. M. Catálogo de otólitos de Carangidae (Osteichthyes Perciformes) do litoral do Estado do Paraná, Brasil. Nerítica, v. 7, n. 1-2, p. 117-129, 1992.

ANDERSON, M. J.; GORLEY, R. N.; CLARKE, K. R. PERMANOVA + for PRIMER: Guide to Software and Statistical Methods. Plymouth: PRIMER-E, 2008.

ARCOS, J. M.; ORO, D.; SOL, D. Competition between the yellow-legged gull Larus cachinnans and Audouin's gull Larus audouinii associated with commercial fishing vessels: the influence of season and fishing fleet. Mar. Biol., v. 816, n. 5 , p. 139, p. $807,2001$.

BARBIERI, E. Abundância temporais de Fregata magnificens (Pelecaniformes: Fregatidae) na Ilha Comprida (São Paulo, Brasil) em 2006 e sua relação com barcos de pesca. Rev. Bras. Ornitol., v. 18, n. 3, p. 164-168, 2010.

BERNARDO, C.; SPACH, L. H.; SCHWARZ JR, R.; STOIEV, B. S.; CATTANI, P. A. A captura incidental de cienídeos em arrasto experimental com rede-de-portas utilizada na pesca do camarão-sete-barbas, Xiphopenaeus kroyeri, no estado do Paraná, Brasil. Arq. Ciênc. Mar, v. 44, n. 2, p. 98-105, 2011.

BRANCO, J. O.; FRACASSO, H. A. A.; MACHADO, I. F.; BOVENDORP, M. S.; VERANI, J. Dieta de Sula leucogaster Boddaert (Sulidae, Aves), nas Ilhas Moleques do Sul, Florianópolis, Santa Catarina, Brasil. Rev. Bras. Zoo., v. 22, n. 4, p. 1044-1049, 2006.

BUGONI, L.; VOOREN, C. M. Feeding ecology of the Common Tern Sterna hirundo in a wintering area in southern Brazil. Ibis, v. 146, n. 3, p. 438-453, 2004.

BIGARELlA, J. J. Contribuição ao Estudo da Planície Litorânea do Estado do Paraná. Braz. Arch. Biol. Technol., v. Jubilee, p. 65-110, 2001.

CARVALHO, B. M.; CORREAA, M. F. M.; VOLPEDO, A. V. Lapillus otoliths of the Cathorops spixii (Spix, Agassiz, 1829) and Genidens genidens (Cuvier, 1829) (Actinopterygii - Ariidae). Acta Sci. Biol. Sci., v. 36, n. 3, p. 343-347, 2014.

CARNIEL, V. L.; KRUL, R. Use of artisanal fishery discards by seabirds on the Paraná Coast of Brazil. Mar. Ornithol., v. 40, n. 1, p. 57-62, 2012.

CASTRO, P. M. G.; GerGOle, M. C.; CARNEIRO, M. H.; MUCINHTO, C. M. D.; SERVO, G. J. M. Crescimento, mortalidade e taxa de explotação do goete, Cynoscion jamaicensis (Perciformes: Sciaenidae), na região sudeste/sul do Brasil. Bol. Inst. Pesca, v. 28, n. 2, p. 141-153, 2002.

CATTANI, A. P.; SANTOS, L. O.; SPACH, H. L.; BUDEL, B. R.; GONDIM GUANAIS, J. H. D. Avaliação da ictiofauna da fauna acompanhante da pesca do camarão sete-barbas do município de Pontal do Paraná, litoral do Paraná, Brasil. Bol. Inst. Pesca, v. 37, n. 2, p. 247-260, 2011. 
CHAVES, P. T. C.; COVA-GRANDO, G.; CALLUF, C. C. H. Demersal ichthyofauna in a continental shelf region on the south coast of Brazil exposed to shrimp trawl fisheries. Acta Biol. Paranaense., v. 32, n. 1-4, p. 69-82, 2003.

CHAVES. P. T.; ROBERT, M. C. Embarcações, artes e procedimentos da pesca artesanal no litoral sul do Estado do Paraná, Brasil. Atlântica, v. 25, n. 1, p. 53-59, 2003.

CORRÊA, M. F. M.; VIANA, M. S. Catálogo dos otólitos sagitta de Sciaenidae (Ostheichthys - Perciformes) do litoral do estado do Paraná, Brasil. Nerítica, v. 7, n. 3, p. 13-41, 1992.

DI BENEDITTO, A. P. M.; RAMOS, R. M. A.; LIMA, N. R. W. Os golfinhos: origem, classificação, captura acidental e habito alimentar. Porto Alegre: Cinco Continentes, 2001. 147 p.

FIGUEIREDO, J. L.; MENEZES, N. A. Manual dos peixes marinhos do Sudeste do Brasil. VI. Teleostei (5). São Paulo: Museu de Zoologia da Universidade de São Paulo, 2000. 116 p.

FREITAS. M. M.; SPACH, H. L.; HOSTIM-SILVA, M. Variação espaço-temporal da assembleia de peixes demersais em uma área de pesca do camarão sete-barbas no sul do Brasil. Neotrop. Biol. Conserv., v. 6, n. 1, p. 44-54, 2011.

GIACCARDI, M.; YORIO, P. Temporal patterns of abundance and waste use by kelp Gull (Larus dominicanus) at an urban and fishery waste site in northern coastal Patagonia, Argentina. Ornitol. Neotrop., v. 15, p. 93-102, 2004.

GOMES, I. D.; CHAVES, P. T. Ictiofauna integrante da pesca de arrasto camaroeiro no litoral sul do Estado do Paraná. Bioikos, v. 20, n. 1, p. 9-13, 2006.

GONZÁLES-SOLIS, J. Impact of fisheries on activity, diet and predatory interactions between yellow-legged and Audouin's gulls breeding at the Chafarinas Islands. Sci. Mar., v. 67, n. Suppl. 2, p. 83-82, 2003.

GRAÇA-LOPES, R.; PUZZI, A.; SEVERINO-RODRIGUES, E.; BARTOLOTTO, A. S.; GUERRA, D. S. F.; FIGUEIREDO, K. T. B. Comparação entre a produção de camarão setebarbas e de fauna acompanhante pela frota de pequeno porte sediada na Praia de Perequê, Estado de São Paulo, Brasil. Bol. Inst. Pesca, v. 28, n. 2, p. 189-194, 2002.

HÜPPOP, O.; WURM, S. Effects of winter fishery activities on resting numbers, food and body condition of large gulls Larus argentatus and L. marinus in the south-eastern North Sea. Mar. Ecol. Prog. Ser., v. 194, p. 241-247, 2000.

KRUL, R. Aves marinhas costeiras do Paraná. In: BRANCO, J. (Org.). Aves marinhas e Insulares Brasileiras: Bioecologia e Conservação. Itajaí: Univali, 2004. p. 37-56.

LEMOS, P. H. B.; CORRÊA, M. F. M.; PINHEIRO, P. C. Catálogo dos otólitos sagitta de Clupeidae (Ostheichthys Clupeiiformes) do litoral do estado do Paraná, Brasil. Arq. Biol. Tecnol., v. 38, n. 3, p. 747-759, 1992.

LEMOS, P. H. B.; CORRÊA, M. F. M.; PINHEIRO, P. C. Catálogo dos otólitos sagitta de Eugraulidae (Ostheichthys Clupeiiformes) do litoral do estado do Paraná, Brasil. Arq. Biol. Tecnol., v. 38, n. 3, p. 731-745, 1995.

LUDYNIA, K.; GARTHE, S.; JORQUERA-LUNA, G. Seasonal and regional variation in the diet of the kelp gull in northern Chile. Waterbirds, v. 28, n. 3, p. 359-365, 2005.

PAIVA, M. P. Recursos pesqueiros estuarinos e marinhos do Brasil. Fortaleza: Universidade Federal do Ceará, 1997. $286 \mathrm{p}$.
PETRACCI, P. L. Diet of Sanderling in Buenos Aires Province, Argentina. Waterbirds, v. 25, n. 3, p. 366-370, 2002.

PINA, J. V.; CHAVES, P. T. Incidência da pesca de arrasto camaroeiro sobre peixes em atividade reprodutiva: uma avaliação no litoral norte de Santa Catarina, Brasil. Atlântica, v. 31, n. 1, p. 99-106, 2009.

PINKAS, L.; OLIPHANT, M. S.; IVERSON, I. L. Food habits of Albacore, Bluefin Tuna, and Bonito in California waters. Calif. Fish. Game., v. 152, p. 1-105, 1971.

ROSSI-WONGTSCHOWSKI, C. L. D. B.; SILIPRANDI, C. C.; BRENHA, M. R.; GONSALES, S. A.; SANTIFICETUR, C.; VAZ-DOS-SANTOS, A. M. Atlas of marine bony fish otoliths (sagittae) of Southeastern- Southern Brazil. Part II: Perciformes (Carangidae, Sciaenidae, Scombridae and Serranidae). Braz. J. Oceanogr., v. 62, n. Spe 1, p. 1-103, 2014.

SCHWARZ JR., R.; FRANCO, A. C. N. P.; SPACH, H. L.; SARPEDONTI, V.; PICHLER, H. A.; NOGUEIRA DE QUEIROZ, G. M. L. Composição e estrutura da ictiofauna demersal na Baía dos PInheiros, Paraná. Braz. J. Aquat. Sci. Technol., v. 10, n. 1, p. 27-39, 2006.

SILVA, M. P.; BASTIDA, R.; DARRIEU, C. Dieta de la Gaivota Cocinera (Larus dominicanus) en zonas costeras de la Provincia de Buenos Aires, Argentina. Ornitol. Neotrop., v. 11, p. 331-339, 2000.

SILVA-COSTA, A.; BUGONI, L. Feeding ecology of Kelp Gulls (Larus dominicanus) in marine and limnetic environments. Aquat. Ecol., v. 47, n. 2, p. 211-224, 2013.

SIMMONS, R. E.; AVERY, D. M.; AVERY, G. Biases in diets determined from pellets and remains: correction factors for a mammal and bird-eating raptor. J. Raptor. Res., v. 25, n. 3, p. 63-67, 1991.

SOUZA, L. M.; CHAVES, P. T. Atividade reprodutiva de peixes (Teleostei) e o defeso da pesca de arrasto no litoral norte de Santa Catarina, Brasil. Rev. Bras. Zool., v. 24, n. 4, p. 11131121, 2007.

TRAVERSI, G. S.; VOOREN, C. M. Interações entre aves marinhas e pesca com arrasto em águas costeiras do sul do Brasil no verão. Rev. Bras. Ornitol., v. 18, n. 3, p. 183-193, 2010.

VAZZOLER, A. E. A. M.; BRAGA, F. M. S. Contribuição para o conhecimento da biologia de Cynoscion jamaicensis (Vaillant and Bocourt, 1883), na área entre Cabo de São Tomé $\left(22^{\circ} 04^{\prime}\right.$ S) e Torres (29 $21^{\prime}$ S). Bol. Inst. Oceanogr., v. 32, n. 2, p. 125-136, 1983.

VEIGA, F. A.; ANGULO, R. J.; MARONE, E.; BRANDINI, F. P. Características sedimentológicas da plataforma continental interna rasa na porção central do litoral paranaense. Bol. Paran. Geoc., v. 55, p. 27-39, 2004.

YORIO, P.; BERTELLOTI, M.; GANDINI, P.; FRERE, E. Kelp gulls Larus dominicanus breeding on the argenine coast: population status and relationship with coastal management and conservation. Mar. Ornithol., v. 26, n. 1-2, p. 11-18, 1998.

YORIO, P.; CAILLE, G. Fish waste as an alternative resource for gulls along the Patagonian coast: availability, use, and potential consequences. Mar. Pollut. Bull., v. 48, n. 7-8, p. 778-783, 2004.

WhitTington, P. A.; MARTIN, A. P.; KLAGES, N. T. W. Status, distribution and conservation implications of the Kelp Gulls (Larus dominicanus) within the Eastern Cape region of South Africa. Emu, v. 106, n. 2, p. 127-139, 2006. 